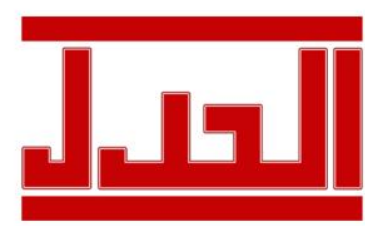

ISSN: $1979-4940$

E-ISSN: 2477-0124
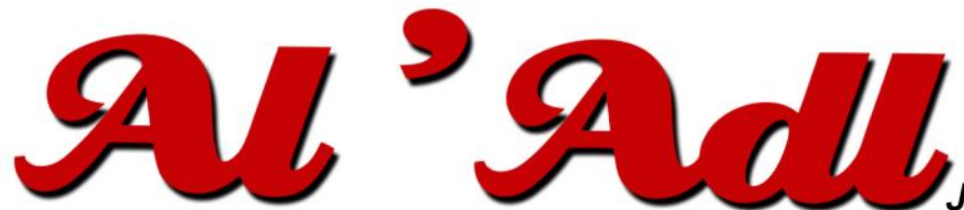

Jurnal Hukum

Editorial Office: Faculty of Law, Islamic University Of Kalimantan,

Jalan Adhyaksa No. 2 Kayutangi Banjarmasin, Kalimantan Selatan, Indonesia (70123)

Email: al_adl@uniska-bjm.ac.id

Web: http://ojs.uniska-bjm.ac.id

\title{
PENEGAKAN HUKUM PIDANA TERHADAP TINDAK PIDANA DI BIDANG PERUMAHAN DAN KAWASAN PERMUKIMAN BERDASARKAN UNDANG-UNDANG NOMOR 1 TAHUN 2011 TENTANG PERUMAHAN DAN KAWASAN PERMUKIMAN
}

\author{
Panca Subagyo \\ Magister Hukum Universitas Singaperbangsa Karawang \\ Jl. HS. Ronggo Waluyo, Paseurjaya, Telukjambe Timur, Kab. Karawang - 41361 \\ Email: pancasubagyo@gmail.com
}

\begin{abstract}
Submitted
: 2 Maret 2021

Revised

: 10 Maret 2021

Accepted

: 23 Maret 2021

Published

: 5 Februari 2021

(C) Licence by CC BY-NC-SA
\end{abstract}

\begin{abstract}
This study aims to analyze the regulation and enforcement of criminal law against housing crimes. The method used in this research is normative legal research which is carried out by reviewing the laws and regulations that are applied to particular legal issues. The results of this study are that criminal law enforcement against housing crimes, especially in judicial enforcement, is still rarely has reached the court. This is because the criminal acts regulated in Act 1/2011 on Housing and Settlement Areas are not pure criminal law, but administrative penal laws which are administrative rules that support by criminal sanctions. Act 1/2011 on Housing and Settlement Areas in addition to regulating criminal sanctions also regulates administrative sanctions, so when there is a violation, it is more likely resolved by administrative law rather than criminal law because of the narrowness of the criminal law. Criminal law will only be used when administrative law is unable to resolve problems. The penalization exists so that Act 1/2011 on Housing and Settlement Areas has a deterrent effect on the offenders of the criminal act.
\end{abstract}

Keywords : Criminal Law Enforcement. Criminal Act. Housing and Settlement Areas

Abstrak

Penelitian ini bertujuan untuk menganalisis pengaturan dan penegakan hukum pidana terhadap tindak pidana di bidang perumahan dan kawasan permukiman. Metode penelitian yang digunakan dalam penelitian ini adalah metode penelitian normatif yakni penelitian hukum yang dilakukan dengan cara mengkaji peraturan perundangundangan yang diterapkan terhadap suatu permasalahan hukum tertentu. Hasil penelitian ini menyatakan bahwa dalam penegakan hukum pidana terhadap tindak pidana di bidang perumahan dan kawasan permukiman, khususnya penegakan hukum yudikatif, masih sangat jarang terjadi kasus tindak pidana di bidang perumahan dan kawasan permukiman yang sampai tahap persidangan. Hal ini disebabkan karena tindak pidana yang diatur dalam Undang-Undang Nomor 1 Tahun 2011 tentang Perumahan dan Kawasan Permukiman tersebut pada dasarnya bukan merupakan kejahatan murni, melainkan hanya hukum administratif yang diperkuat dengan sarana penal, atau hukum administratif yang diberikan sanksi pidana. Undang-Undang Nomor 1 Tahun 2011 
tentang Perumahan dan Kawasan Permukiman selain mengatur sanksi pidana juga mengatur sanksi administrasi, maka ketika terjadi pelanggaran di bidang perumahan dan kawasan permukiman, lebih banyak diselesaikan dengan hukum administrasi daripada hukum pidana karena sifat hukum pidana yang menderitakan. Hukum pidana hanya akan digunakan ketika hukum administrasi tidak mampu menyelesaikan persoalan di bidang perumahan dan kawasan permukiman. Adanya penalisasi tersebut agar Undang-Undang Nomor 1 Tahun 2011 tentang Perumahan dan Kawasan Permukiman mempunyai deterrent effect terhadap pelaku tindak pidananya.

Kata Kunci : Penegakan hukum pidana; Tindak pidana; Perumahan dan Kawasan Permukiman.

\section{PENDAHULUAN}

Indonesia merupakan negara yang mempunyai jumlah penduduk terbesar keempat di dunia setelah China, India dan Amerika Serikat. Dengan jumlah penduduk yang sangat besar tersebut membuat pemerintah harus berpikir lebih keras bagaimana caranya semua warga negaranya bisa memiliki tempat tinggal yang layak. Negara bertanggung jawab melindungi segenap bangsa Indonesia melalui penyelenggaraan perumahan dan kawasan permukiman agar masyarakat mampu bertempat tinggal serta menghuni rumah yang layak dan terjangkau.

Pemerintah perlu lebih berperan dalam menyediakan dan memberikan kemudahan dan bantuan perumahan dan kawasan permukiman bagi masyarakat melalui penyelenggaraan perumahan dan kawasan permukiman yang berbasis kawasan serta keswadayaan masyarakat, sehingga merupakan satu kesatuan fungsional dalam wujud tata ruang fisik, kehidupan ekonomi, dan sosial budaya yang mampu menjamin kelestarian lingkungan hidup, hal ini sejalan dengan semangat demokrasi, otonomi daerah, dan keterbukaan dalam tatanan kehidupan bermasyarakat, berbangsa, dan bernegara.

Pertumbuhan dan pembangunan wilayah yang kurang memperhatikan keseimbangan bagi kepentingan masyarakat berpenghasilan rendah mengakibatkan kesulitan masyarakat untuk memperoleh rumah yang layak dan terjangkau, hal ini merupakan persoalan yang dihadapi oleh pemerintah agar masyarakat berpenghasilan rendah juga bisa memiliki rumah yang layak dengan cara memberikan subsidi terhadap mereka yang membeli rumah dengan cara KPR di perbankan yang telah ditunjuk oleh pemerintah.

Dalam rangka mendukung dan melindungi seluruh warga Negara Indonesia melalui penyelenggaraan perumahan dan kawasan permukiman, pemerintah telah menerbitkan Undang-undang Nomor 1 Tahun 2011 tentang Perumahan dan Kawasan Permukiman. Undang-Undang tersebut merupakan pengganti dari Undang-Undang Nomor 4 Tahun 1992 tentang Perumahan dan Permukiman yang sudah tidak sesuai lagi dengan perkembangan dan kebutuhan perumahan dan permukiman yang layak, aman, serasi dan teratur. 
Pada awalnya, ketentuan mengenai perumahan diatur dalam Undang-Undang Nomor 41 Tahun 1964 tentang Peraturan Pemerintah Pengganti Undang-Undang Nomor 6 Tahun 1962 tentang Pokok-Pokok Perumahan. Undang-Undang Nomor 41 Tahun 1964 dinyatakan tidak berlaku oleh Undang Nomor 4 Tahun 1992 tentang Perumahan dan Permukiman. Undang Nomor 4 Tahun 1992 dinyatakan tidak berlaku oleh Undang Nomor 1 Tahun 2011 tentang Perumahan dan Kawasan Permukiman. ${ }^{1}$

Namun, berdasarkan ketentuan Pasal 164 Undang-Undang Nomor 1 Tahun 2011 tentang Perumahan dan Permukiman, semua peraturan perundang-undangan yang merupakan peraturan pelaksanaan dari Undang-Undang Nomor 4 Tahun 1992 tentang Perumahan dan Permukiman (Lembaran Negara Republik Indonesia Tahun 1992 Nomor 23, Tambahan Lembaran Negara Republik Indonesia Nomor 3469), dan peraturan perundang-undangan lainnya mengenai perumahan dan permukiman, dinyatakan tetap berlaku sepanjang tidak bertentangan atau belum diganti dengan peraturan pelaksanaan yang baru berdasarkan Undang-Undang Nomor 1 Tahun 2011 tentang Perumahan dan Kawasan Permukiman.

Peraturan perundang-undangan yang merupakan pelaksanaan Undang-Undang Nomor 4 Tahun 1992, antara lain: a. Peraturan Pemerintah Nomor 44 Tahun 1994 tentang Penghunian Rumah oleh Bukan Pemilik; b. Peraturan Pemerintah Nomor 80 Tahun 1999 tentang Kawasan Siap Bangun dan Lingkungan Siap Bangun yang Berdiri Sendiri; c. Peraturan Pemerintah Nomor 31 Tahun 2005 tentang Perubahan Atas Peraturan Pemerintah Nomor 40 Tahun 1994 tentang Rumah Negara; d. Peraturan Pemerintah Nomor 63 Tahun 2000 tentang Badan Kebijaksanaan dan Pengendalian Pembangunan Perumahan dan Permukiman Nasional.

Undang-Undang Nomor 1 Tahun 2011 tentang Perumahan dan Kawasan Permukiman terdiri dari 167 pasal. Ketentuan mengenai sanksi dalam penyelenggaraan perumahan dan kawasan permukiman diatur dalam Pasal 150 sampai dengan Pasal 163 Undang-Undang Nomor 1 Tahun 2011. Ada 3 (tiga) macam sanksi yang ditetapkan dalam Undang-Undang Nomor 1 Tahun 2011, yaitu sanksi administratif, sanksi pidana, dan sanksi tambahan.

Ketentuan mengenai sanksi pidana dalam penyelenggaraan perumahan dan kawasan permukiman diatur dalam Pasal 151 sampai dengan Pasal 163 Undang-Undang Nomor 1 Tahun 2011 tentang Perumahan dan Kawasan Permukiman. Ada 3 (tiga) macam sanksi pidana dalam Undang-Undang Nomor 1 Tahun 2011, yaitu pidana penjara, pidana kurungan, dan denda.

\footnotetext{
${ }^{11}$ Pasal 164 UU No 1 Tahun 2011 Tentang Perumahan dan Kawasan Permukiman.
} 
Selain pidana penjara, pidana kurungan dan denda, Undang-Undang Nomor 1 Tahun 2011 tentang Perumahan dan Kawasan Permukiman juga menetapkan sanksi tambahan yang terdapat dalam Pasal 151 ayat (2), Pasal 153 ayat (3), dan Pasal 161 ayat (2) undang-undang tersebut. Adapun bentuk sanksi tambahan dalam penyelenggaraan perumahan dan kawasan permukiman, antara lain: membangun kembali perumahan sesuai dengan kriteria, spesifikasi, persyaratan, prasarana, sarana, dan utilitas umum; pencabutan izin; dan pembongkaran lingkungan siap bangun yang biayanya ditanggung oleh pelaku. Namun, setelah terbitnya Undang-Undang Nomor 11 Tahun 2020 Tentang Cipta Kerja, sanksi pidana tambahan yang terdapat dalam Pasal 151 ayat (2) dan Pasal 153 telah dicabut, sehingga saat ini pidana tambahan yang masih ada hanya terdapat di dalam Pasal 161 ayat (2) dengan bentuk pidana tambahan berupa pembongkaran lingkungan siap bangun yang biayanya ditanggung oleh pelaku.

Dengan masuknya revisi Undang-Undang Nomor 1 Tahun 2011 tentang Perumahan dan Kawasan Permukiman dalam Undang-Undang Cipta Kerja tersebut telah mengindikasikan bahwa sektor perumahan dan kawasan permukiman merupakan sektor yang penting dalam upaya pemerintah membuka lapangan kerja sebanyak-banyaknya. Namun, secara substansial yang diatur dalam Undang-Undang tentang Perumahan dan Kawasan Permukiman tersebut apakah telah sesuai dengan harapan, mengingat undang-undang tersebut menggunakan sarana hukum pidana. Selain itu apakah penegakan hukumnya telah efektif dan mempunyai implikasi yang baik terhadap sektor perumahan dan kawasan permukiman.

Jika dilihat sampai saat ini, penegakan hukum pidana terhadap tindak pidana yang dikualifikasikan dalam Undang-Undang Perumahan dan Kawasan Permukiman masih sangat minim sekali. Hal ini terjadi karena di dalam undang-undang tersebut, selain mengatur ketentuan pidana, juga mengatur sanksi administratif. Kasus yang pernah ada terhadap penegakan hukum pidana di bidang perumahan dan kawasan permukiman salah satunya pernah terjadi di Kota Padang, dengan terdakwa Elvi Madreani yang oleh Pengadilan Negeri Padang, terdakwa dinyatakan terbukti bersalah melakukan tindak pidana di bidang perumahan dan kawasan permukiman dan dijatuhkan hukuman pidana penjara selama 1 (satu) tahun.

Terdakwa Elvi Madreani oleh Pengadilan Negeri Padang dianggap telah melakukan tindak pidana menjual satuan lingkungan perumahan atau lisiba yang belum menyelesaikan status hak atas tanahnya, sebagaimana diatur dalam Pasal 154 Undang-Undang Nomor 1 Tahun 2011 tentang Perumahan dan Kawasan Permukiman. Ancaman pidana yang diatur 
dalam Pasal 154 sendiri adalah pidana penjara paling lama 5 (lima) tahun atau denda paling banyak Rp.5.000.000.000,00 (lima miliar rupiah).

Penelitian yang membahas tindak pidana di bidang perumahan dan kawasan permukiman sudah pernah dilakukan oleh peneliti sebelumnya. Hal ini sesuai dengan penelusuran yang dilakukan dengan cara melihat beberapa literature yang ada, maka setidaknya ditemukan satu literature yang erat kaitannya dengan permasalahan yang ada dalam penelitian ini, yaitu Zinda Zhafirah pada tahun 2019 dari Universitas Sriwijaya dengan berjudul Tinjauan Yuridis Terhadap Tindak Pidana di Bidang Perumahan dan Kawasan Pemukiman. $^{2}$

Dalam penelitiannya membahas tentang bagaimana pertanggungjawaban pidana dan sanksi pidana terhadap pelaku tindak pidana di bidang perumahan dan kawasan permukiman, serta membahas mengenai hambatan-hambatan yang terjadi dalam penerapan sanksi pidana yang diatur dalam Undang-Undang Nomor 1 Tahun 2011 tentang Perumahan dan Kawasan Permukiman.

Dalam penelitian ini terdapat perbedaan rumusan masalah yang diambil dengan penelitian sebelumnya, walaupun tema dari penelitian sama-sama membahas tindak pidana di bidang perumahan dan kawasan permukiman. Penelitian yang diteliti di sini adalah membahas pengaturan tindak pidana di bidang perumahan dan kawasan permukiman beserta penegakan hukum pidananya. Adapun penegakan hukum pidana di sini penulis menganalisis putusan pengadilan yang telah berkekuatan hukum tetap, yakni Putusan Mahkamah Agung Nomor 635 K/Pid.Sus/2019.

\section{RUMUSAN MASALAH}

Berdasarkan latar belakang masalah diatas, maka rumusan masalah yang ditawarkan dalam penelitian ini adalah :

1. Bagaimana pengaturan tindak pidana di bidang perumahan dan kawasan permukiman berdasarkan Undang-Undang Nomor 1 Tahun 2011 tentang Perumahan dan Kawasan Permukiman?

2. Bagaimana penegakan hukum pidana terhadap tindak pidana di bidang perumahan dan kawasan permukiman berdasarkan Undang-Undang Nomor 1 Tahun 2011 tentang Perumahan dan Kawasan Permukiman?

${ }^{2}$ Zinda Zhafirah, (2019). Tinjauan Yuridis Terhadap Tindak Pidana di Bidang Perumahan dan Kawasan Pemukiman. Universitas Sriwijaya, hlm. 9. 
3. Bagaimana analisis terhadap putusan Mahkamah Agung Nomor 635 K/Pid.Sus/2019 atas tindak pidana di bidang perumahan dan kawasan permukiman?

\section{TUJUAN PENELITIAN}

Penelitian ini mempunyai tujuan untuk mengkaji pengaturan tindak pidana di bidang perumahan dan kawasan permukiman berdasarkan Undang-Undang Nomor 1 Tahun 2011 tentang Perumahan dan Kawasan Permukiman, dan mengkaji bagaimana penegakan hukum pidana terhadap tindak pidana di bidang perumahan dan kawasan permukiman berdasarkan Undang-Undang Nomor 1 Tahun 2011 tentang Perumahan dan Kawasan Permukiman tersebut, serta menganalisis terhadap Putusan Mahkamah Agung Nomor 635 K/Pid.Sus/2019 atas tindak pidana di bidang perumahan dan kawasan permukiman.

\section{METODE PENELITIAN}

Karya ilmiah penelitian hukum diharuskan menggunakan metode penelitian hukum. Ilmu hukum berusaha untuk menampilkan hukum secara integral sesuai dengan kebutuhan kajian ilmu hukum itu sendiri, sehingga metode penelitian dibutuhkan untuk memperoleh arah penelitian yang komprehensif. ${ }^{3}$ Sebenarnya ilmu hukum mempunyai ciri-ciri sebagai ilmu yang bersifat preskriptif dan terapan. Dalam preskriptif, ilmu hukum mempelajari tujuan hukum, nilai-nilai keadilan dalam suatu hukum, baik buruk suatu aturan hukum, konsepkonsep dan norma hukum. sedangkan dalam ilmu terapan, ilmu hukum menetapkan suatu prosedur, ketentuan-ketentuan dan batasan-batasan dalam menegakan suatu aturan hukum. ${ }^{4}$

Metode penelitian yang akan digunakan dalam penulisan hukum ini adalah penelitian normatif. Metode penelitian hukum normatif dapat dimaknai sebagai penelitian hukum dalam tataran norma, kaidah, asas-asas, teori, filosofi, dan aturan hukum guna mencari solusi atau jawaban atas permasalahan baik dalam bentuk kekosongan hukum, konflik norma, atau kekaburan norma. Dengan demikian metode penelitian hukum normatif memiliki karakteristik sebagai penelitian kepustakaan atau

\footnotetext{
${ }^{3}$ Yati Nurhayati, "Perdebatan Metode Normatif dengan Metode Empirik Dalam Penelitian Ilmu Hukum Ditinjau Dari Karakter, Fungsi dan Tujuan Ilmu Hukum", Jurnal Al Adl, Volume 5 Nomor 10, 2013, hlm. 15.

${ }^{4}$ Yati Nurhayati, Pengantar Ilmu Hukum, Nusa Media, Bandung, 2020, hlm. 9.
} 
literature research yang berbeda dengan metode penelitian empiris (non-doktrinal) yang berkarakteristik penelitian lapangan (field study). ${ }^{5}$

Penelitian normatif yang memberikan penjelasan yang sistematis atas peraturan yang mengatur kategori hukum tertentu. Karya tulis ilmiah yang dibuat ini mengacu pada peraturan perundang-undangan serta berbagai literatur yang terkait dengan tindak pidana di bidang perumahan dan kawasan permukiman. Penelitian ini dilakukan dengan menginventarisir ketentuan hukum positif berkaitan dengan tindak pidana di bidang perumahan dan kawasan permukiman.

Penelitian ini terdiri dari beberapa pendekatan. Pendekatan yang pertama adalah pendekatan peraturan perundang-undangan (statute approach) Pendekatan ini dilakukan dengan cara menganalisis dan semua undang-undang dan regulasi yang berkaitan dengan isu hukum yang timbul. Bagi penelitian untuk kegiatan akademis, perlu mencari ratio legis dan dasar ontologism lahirnya undang-undang tersebut. Sehingga dapat ditemukan suatu aturan yang relevan untuk memecahkan isu hukum yang didapati. ${ }^{6}$

Pendekatan kedua adalah Pendekatan konseptual (conceptual approach). Pendekatan ini dilakukan dengan cara mencari teori serta doktrin yang erat kaitannya dengan isu tersebut yang kemudian dijadikan sebagai acuan agar dapat memahami suatu pandangan-pandangan dan doktrin-doktrin dalam membangun suatu argumentasi hukum dalam memecahkan isu yang sedang dihadapi. ${ }^{7}$ Pendekatan conceptual approach menghubungkan konsep yang telah ada dengan isu hukum terkait dengan tindak pidana di bidang perumahan dan kawasan permukiman.

Bahan hukum yang digunakan adalah berupa bahan hukum primer. Bahan hukum primer bersumber pada peraturan perundang-undangan yang ada kaitannya dengan permasalahan sebagaimana dipaparkan dalam penelitian ini. Bahan hukum primer yang digunakan sebagai berikut:

a. Venddu Reglement.

b. Undang-Undang Dasar Negara Republik Indonesia Tahun 1945.

c. Undang-Undang Nomor 4 Tahun 1992 tentang Perumahan dan Permukiman.

d. Undang-Undang Nomor 1 Tahun 2011 tentang Perumahan dan Kawasan Permukiman.

e. Undang-Undang Nomor 11 Tahun 2020 tentang Cipta Kerja.

\footnotetext{
${ }^{5}$ Nurhayati, Y., Ifrani, I., \& Said, M. Y. (2021). Metodologi Normatif Dan Empiris Dalam Perspektif Ilmu Hukum. Jurnal Penegakan Hukum Indonesia, 2(1), 1-20. https://doi.org/10.51749/jphi.v2i1.14

${ }^{6}$ Peter Mahmud Marzuki. (2005). Penelitian Hukum, Surabaya: Kencana, hlm. 93-94

${ }^{7}$ Ibid., hlm. 95
} 
Bahan hukum sekunder meliputi semua jenis publikasi berupa hukum yang bukan merupakan dokumen-dokumen resmi. Publikasi tentang hukum seperti buku-buku teks, kamus-kamus hukum, jurnal hukum.

\section{PEMBAHASAN}

\section{A. Pengaturan Tindak Pidana Dalama Undang-Undang Perumahan dan Kawasan Permukiman}

Di Indonesia, regulasi yang mengatur perumahan dan kawasan permukiman telah diatur dalam Undang-undang Nomor 1 Tahun 2011 tentang Perumahan dan Kawasan Permukiman. Memahami konsep hukum pidana dalam undang-undang perumahan dan kawasan permukiman adalah memahami konsep hukum pidana itu sendiri. Hal ini karena hukum pidana yang diatur dalam undang-undang perumahan dan kawasan permukiman merupakan bagian dari hukum pidana. Moeljatno mengartikan hukum pidana sebagai bagian dari keseluruhan hukum yang berlaku di suatu negara, yang mengadakan dasar-dasar dan aturan-aturan untuk: ${ }^{8}$

1. Menentukan perbuatan-perbuatan yang tidak boleh dilakukan, yang dilarang, dengan disertai ancaman atau sanksi pidana tertentu bagi siapa saja yang melanggarnya;

2. Menentukan kapan dan dalam hal apa kepada mereka yang telah melakukan laranganlarangan itu dapat dikenakan atau dijatuhi pidana sebagaimana yang telah diancamkan;

3. Menentukan dengan cara bagaimana pengenaan pidana itu dapat dilaksanakan apabila orang yang diduga telah melanggar ketentuan tersebut.

Van Bemmelen secara eksplisit mengartikan hukum pidana dalam dua hal, yaitu hukum pidana materiel dan hukum pidana formal. Menurutnya, hukum pidana materiel terdiri atas tindak pidana yang disebut berturut-turut, peraturan umum yang dapat diterapkan terhadap perbuatan itu dan pidana yang diancamkan terhadap perbuatan itu. Sementara itu, hukum pidana formal adalah mengatur cara bagaimana acara pidana seharusnya dilakukan dan menentukan tata tertib yang harus diperhatikan pada kesempatan itu. ${ }^{9}$

Wirjono Prodjodikoro memberikan pengertian hukum pidana ke dalam hukum pidana materiel dan hukum pidana formal. Menurutnya isi hukum pidana materiel adalah penunjukan dan gambaran perbuatan-perbuatan yang diancam dengan hukum pidana; penunjukan syarat umum yang harus dipenuhi agar perbuatan itu merupakan perbuatan yang pembuatnya dapat dihukum pidana; penunjukan orang atau badan hukum yang pada umumnya dapat dihukum pidana; dan penunjukan jenis hukuman pidana yang dapat dijatuhkan. Hukum pidana formal

\footnotetext{
${ }^{8}$ Moeljatno. 2008. Asas-Asas Hukum Pidana, Jakarta: Renika Cipta, hlm. 1.

${ }^{9}$ Mr. J. M. van Bemmelen. 1987. Hukum Pidana I, Bandung: Bina Cipta, hlm. 2-3.
} 
(hukum acara pidana) berhubungan erat dengan diadakannya hukum pidana sehingga merupakan suatu rangkaian peraturan yang memuat cara bagaimana badan-badan pemerintah yang berkuasa, yaitu kepolisian, kejaksaan, dan pengadilan harus bertindak guna mencapai tujuan negara dengan mengadakan hukum pidana. ${ }^{10}$

Sudarto mendefinisikan hukum pidana sebagai hukum yang memuat aturan-aturan hukum yang mengikatkan kepada perbuatan-perbuatan yang memenuhi syarat tertentu suatu akibat pidana. Sejalan dengan hal ini, Kitab Undang-Undang Hukum Pidana (KUHP) memuat dua hal pokok, yaitu sebagai berikut:

1. KUHP memuat pelukisan-pelukisan dari perbuatan-perbuatan yang diancam, yang memungkinkan pengadilan menjatuhkan pidana. Jadi, disini seolah-olah negara menyatakan kepada umum dan juga kepada para penegak hukum, perbuatan-perbuatan apa yang dilarang dan siapa yang dapat dipidana.

2. KUHP menetapkan dan mengumumkan reaksi apa yang akan diterima oleh orang yang melakukan perbuatan-perbuatan yang dilarang itu. Dalam hukum pidana modern reaksi ini tidak hanya berupa pidana, tetapi juga apa yang disebut dengan tindakan, yang bertujuan untuk melindungi masyarakat dari perbuatan-perbuatan yang merugikannya. ${ }^{11}$

Dengan mengacu kepada beberapa pengertian hukum pidana di atas, hukum pidana dalam undang-undang perumahan dan kawasan permukiman adalah aturan-aturan hukum pidana di bidang perumahan dan kawasan permukiman yang menentukan:

1. Perbuatan-perbuatan yang dilarang atau tidak boleh dilakukan dan diancam dengan sanksi pidana bagi siapa saja yang melakukannya;

2. Menentukan kapan seseorang atau korporasi yang melakukan perbuatan yang dilarang dimintai pertanggungjawaban pidana sehingga sanksi pidana layak dijatuhkan kepadanya;

3. Menentukan kapan dan dalam hal apa kepada mereka yang telah melakukan laranganlarangan itu dapat dikenakan atau dijatuhi pidana sebagaimana yang telah diancamkan.

Rumusan pengertian tersebut menunjukkan bahwa dalam penelitian ini membatasi pengertian hukum pidana di bidang perumahan dan kawasan permukiman hanya pada hukum pidana materiel dan hukum pidana formal. Aspek hukum pidana materiel terkait poin 1 dan 2 , sedangkan aspek hukum pidana formal terkait poin 3. Aspek hukum pidana formal yang dibahas dalam buku ini adalah ketentuan hukum acara pidana dalam Undang-Undang Nomor 8 Tahun 1981 tentang Kitab Undang-Undang Hukum Acara Pidana. Pengertian hukum pidana

\footnotetext{
${ }^{10}$ Wirjono Prodjodikoro. 1962. Hukum Acara Pidana di Indonesia, Bandung: Sumur, hlm.13.

${ }^{11}$ Sudarto. 1977. Hukum dan Hukum Pidana, Bandung: Alumni, hlm. 100-101.
} 
di bidang perumahan dan kawasan permukiman, dengan demikian mengacu kepada hukum pidana materiel yang meliputi tindak pidana, pertanggungjawaban pidana, dan sanksi pidana. Sedangkan hukum pidana formal berupa penyidikan, penuntutan, dan pemeriksaan di sidang pengadilan yang diatur di dalam undang-undang.

Adapun tindak pidana yang diatur dalam Undang-Undang Nomor 1 Tahun 2011 tentang Perumahan dan Kawasan Permukiman, terdapat di dalam Pasal 151 sampai dengan Pasal 163 dengan penjelasan sebagai berikut:

\section{Pasal 151}

Substansi Pasal 151 Undang-Undang Nomor 1 Tahun 2011 telah diubah oleh UndangUndang Nomor 11 Tahun 2020. Dalam Undang-Undang Nomor 1 Tahun 2011, substansi Pasal 151 yang awalnya berisi dua ayat, oleh Undang-Undang Nomor 11 Tahun 2020 diubah menjadi satu ayat saja. Adapun rumusan Pasal 151 setelah diubah oleh Undang-Undang Nomor 11 Tahun 2020 berbunyi sebagai berikut: ${ }^{12}$

"Setiap orang yang menyelenggarakan pembangunan perumahan, yang membangun perumahan tidak sesuai dengan kriteria, spesifikasi, persyaratan, prasarana, sarana, dan utilitas umum yang diperjanjikan sebagaimana dimaksud dalam Pasal 134 yang mengakibatkan timbulnya korban/kerusakan terhadap kesehatan, keselamatan, keamanan, dan lingkungan, dipidana dengan pidana denda paling banyak Rp5.000.000.000,00 (lima miliar rupiah)”.

Unsur subjektif Pasal 151 adalah "setiap orang”, sedangkan unsur objektifnya berupa "menyelenggarakan pembangunan perumahan, yang tidak membangun perumahan sesuai dengan kriteria, spesifikasi, persyaratan, prasarana, sarana, dan utilitas umum yang diperjanjikan yang mengakibatkan timbulnya korban/kerusakan terhadap kesehatan, keselamatan, keamanan, dan lingkungan”. Pasal 151 merupakan ketentuan pidana dari norma larangan yang terdapat di dalam Pasal 134. Substansi Pasal 134 berisi tentang larangan menyelenggarakan pembangunan perumahan yang tidak sesuai dengan kriteria, spesifikasi, persyaratan, prasarana, sarana, dan utilitas umum yang diperjanjikan, dan standar.

Jika mencermati Pasal 134, substansinya mengharuskan pembangunan perumahan sesuai dengan kriteria, spesifikasi, persyaratan, prasarana, sarana dan utilitas umum yang diperjanjikan, dan standar. Artinya harus ada kesesuaian antara aktual fisik yang telah dibangun dengan rencana pembangunan yang diperjanjikan sebelumnya.

\footnotetext{
${ }^{12}$ Undang-Undang Nomor 11 Tahun 2020, Pasal 50 angka 16.
} 
Yang dimaksud dengan prasarana adalah kelengkapan dasar fisik lingkungan hunian yang memenuhi standar tertentu untuk kebutuhan bertempat tinggal yang layak, sehat, aman, dan nyaman. ${ }^{13}$ Sedangkan sarana diartikan sebagai fasilitas dalam lingkungan hunian yang berfungsi untuk mendukung penyelenggaraan dan pengembangan kehidupan sosial, budaya, dan ekonomi. ${ }^{14}$ Adapun utilitas umum, didefinisikan sebagai kelengkapan penunjang untuk pelayanan lingkungan hunian. ${ }^{15}$

Yang membedakan substansi Pasal 151 sebelum diubah dengan setelah diubah oleh Undang-Undang Nomor 11 Tahun 2020, yaitu terdapat penambahan kata "yang mengakibatkan timbulnya korban/kerusakan terhadap kesehatan, keselamatan, keamanan, dan lingkungan" pada substansi Pasal 151 perubahan. Artinya, apabila pada Pasal 151 sebelum perubahan tindak pidana tersebut termasuk delik formil, sedangkan pada Pasal 151 setelah perubahan menjadi delik materiel, karena harus menimbulkan akibat, yang dalam hal ini akibat timbulnya korban/kerusakan terhadap kesehatan, keselamatan, keamanan, dan lingkungan.

Selain itu, perbedaan lain terhadap Pasal 151 sebelum diubah dengan setelah diubah oleh Undang-Undang Nomor 11 Tahun 2020, yaitu penghilangannya sanksi tindakan. Jika pada Pasal 151 sebelum perubahan terdapat Pasal 151 ayat (2) yang mengatur pidana tambahan berupa membangun kembali perumahan sesuai dengan kriteria, spesifikasi, persyaratan, prasarana, sarana, dan utilitas umum yang diperjanjikan, sedangkan pada Pasal 151 setelah perubahan ketentuan pidana tersebut dihapus. Adapun substansi Pasal 151 ayat (2) sebelum dihapus oleh Undang-Undang Nomor 11 Tahun 2020 adalah sebagai berikut: ${ }^{16}$

Selain pidana sebagaimana dimaksud pada ayat (1) pelaku dapat dijatuhi pidana tambahan berupa membangun kembali perumahan sesuai dengan kriteria, spesifikasi, persyaratan, prasarana, sarana, dan utilitas umum yang diperjanjikan.

Sanksi pidana yang diancamkan oleh Pasal 151 sebelum diubah oleh Undang-Undang Nomor 11 Tahun 2020, pidana tersebut bersifat kumulatif, bukan alternatif. Artinya terhadap pelaku delik yang melakukan perbuatan sebagaimana dimaksud dalam Pasal 134 dikenakan 2 sanksi pidana sekaligus, yakni pidana denda paling banyak Rp5.000.000.000,00 (lima miliar rupiah), serta pidana tambahan berupa membangun kembali perumahan sesuai dengan kriteria, spesifikasi, persyaratan, prasarana, sarana, dan utilitas umum yang diperjanjikan.

\footnotetext{
${ }^{13}$ Undang-Undang Nomor 1 Tahun 2011, Pasal 1 angka 21.

${ }^{14}$ Ibid., Pasal 1 angka 22

${ }^{15}$ Ibid., Pasal 1 angka 23

${ }^{16}$ Ibid., Pasal 151 ayat (2)
} 
Substansi Pasal 151 berisi dua ayat. Rumusan Pasal 151 ayat (1) berbunyi sebagai berikut: ${ }^{17}$

“ Orang yang menyelenggarakan pembangunan perumahan, yang tidak membangun perumahan sesuai dengan kriteria, spesifikasi, persyaratan, prasarana, sarana, dan utilitas umum yang diperjanjikan sebagaimana dimaksud dalam Pasal 134, dipidana dengan pidana denda paling banyak Rp5.000.000.000,00 (lima miliar rupiah)."

Unsur subjektif Pasal 151 (1) adalah "setiap orang", sedangkan unsur objektifnya berupa "menyelenggarakan pembangunan perumahan, yang tidak membangun perumahan sesuai dengan kriteria, spesifikasi, persyaratan, prasarana, sarana, dan utilitas umum yang diperjanjikan". Pasal 151 ayat (1) merupakan ketentuan pidana dari norma larangan yang terdapat di dalam Pasal 134. Substansi Pasal 134 berisi tentang larangan menyelenggarakan pembangunan perumahan, yang tidak membangun perumahan sesuai dengan kriteria, spesifikasi, persyaratan, prasarana, sarana, dan utilitas umum yang diperjanjikan.

Jika mencermati Pasal 134, substansinya mengharuskan pembangunan perumahan sesuai dengan kriteria, spesifikasi, persyaratan, prasarana, sarana dan utilitas umum yang diperjanjikan. Artinya harus ada kesesuaian antara aktual fisik yang telah dibangun dengan rencana pembangunan yang diperjanjikan sebelumnya.

Yang dimaksud dengan prasarana adalah kelengkapan dasar fisik lingkungan hunian yang memenuhi standar tertentu untuk kebutuhan bertempat tinggal yang layak, sehat, aman, dan nyaman. ${ }^{18}$ Sedangkan sarana diartikan sebagai fasilitas dalam lingkungan hunian yang berfungsi untuk mendukung penyelenggaraan dan pengembangan kehidupan sosial, budaya, dan ekonomi. ${ }^{19}$ Adapun utilitas umum, didefinisikan sebagai kelengkapan penunjang untuk pelayanan lingkungan hunian. ${ }^{20}$

Pasal 151 ayat (2) mengatur tentang sanksi pidana tambahan terhadap pelaku tindak pidana yang melanggar Pasal 151 ayat (1). Adapun substansi Pasal 151 ayat (2) sebagai berikut: ${ }^{21}$

"Selain pidana sebagaimana dimaksud pada ayat (1) pelaku dapat dijatuhi pidana tambahan berupa membangun kembali perumahan sesuai dengan kriteria, spesifikasi, persyaratan, prasarana, sarana, dan utilitas umum yang diperjanjikan".

Sanksi pidana dalam Pasal 151 ayat (1) dan ayat (2) merupakan sanksi terhadap pelaku delik yang melanggar norma larangan yang diatur dalam Pasal 134. Pidana tersebut bersifat

17 Pasal 151 ayat (1) Undang-Undang Nomor 1 Tahun 2011 Tentang Perumahan dan Kawasan Permukiman.

\footnotetext{
${ }^{18}$ Ibid., Pasal 1 angka 21.

${ }^{19}$ Ibid., Pasal 1 angka 22.

${ }^{20}$ Ibid., Pasal 1 angka 23.

${ }^{21}$ Ibid., Pasal 151 ayat (2).
} 
kumulatif, bukan alternatif. Artinya terhadap pelaku delik yang melakukan perbuatan sebagaimana dimaksud dalam Pasal 134 dikenakan 2 sanksi pidana sekaligus, yakni pidana denda paling banyak Rp5.000.000.000,00 (lima miliar rupiah), serta pidana tambahan berupa membangun kembali perumahan sesuai dengan kriteria, spesifikasi, persyaratan, prasarana, sarana, dan utilitas umum yang diperjanjikan.

2. Pasal 152

Pasal 152 hanya memiliki satu ayat. Adapun rumusan Pasal 152 sebagai berikut: ${ }^{22}$

"Setiap orang yang menyewakan atau mengalihkan kepemilikannya atas rumah umum kepada pihak lain sebagaimana dimaksud dalam Pasal 135, dipidana dengan pidana denda paling banyak Rp50.000.000,00 (lima puluh juta rupiah)".

Hal yang membedakan antara rumusan dalam Pasal 151 ayat (1) dan rumusan Pasal 152 di atas yakni apabila dalam Pasal 151 ayat (1) yang diancam pidana adalah setiap orang yang menyelenggarakan perumahan yang tidak membangun perumahan sesuai yang diperjanjikan, sedangkan di dalam Pasal 152 yang diancam pidana adalah setiap orang yang menyewakan atau mengalihkan kepemilikannya atas rumah umum kepada pihak lain.

Ancaman pidana di dalam Pasal 152 merupakan ancaman pidana terhadap norma larangan yang disebutkan dalam pasal 135, yakni larangan terhadap setiap orang yang menyewakan atau mengalihkan kepemilikannya atas rumah umum kepada orang lain. Adapun definisi dari rumah umum sendiri dijelaskan di dalam Pasal 1 angka 10 yaitu rumah yang diselenggarakan untuk memenuhi kebutuhan rumah bagi masyarakat berpenghasilan rendah. ${ }^{23}$

Unsur subjektif dalam Pasal 152 adalah "setiap orang”, sedangkan unsur objektifnya adalah "yang menyewakan atau mengalihkan kepemilikannya atas rumah umum kepada pihak lain".

\section{Pasal 153}

Ketentuan pidana yang terdapat dalam Pasal 153 Undang-Undang Nomor 1 Tahun 2011 telah diubah oleh Undang-Undang Nomor 11 Tahun 2020 menjadi sanksi administratif. Sebelum dilakukan perubahan oleh Undang-Undang Nomor 11 Tahun 2020, ancaman pidana yang terdapat dalam Pasal 153 adalah pidana denda paling banyak Rp5.000.000.000,00 (lima miliar rupiah) dan pidana tambahan berupa pencabutan izin.

\section{Pasal 154}

Rumusan ketentuan Pasal 154 menegaskan sebagai berikut: ${ }^{24}$

\footnotetext{
${ }^{22}$ Ibid., Pasal 152.

${ }^{23}$ Ibid., Pasal 1 angka 10.

${ }^{24}$ Ibid., Pasal 154.
} 
Setiap orang yang menjual satuan lingkungan perumahan atau Lisiba yang belum menyelesaikan status hak atas tanahnya sebagaimana dimaksud dalam Pasal 137, dipidana dengan pidana penjara paling lama 5 (lima) tahun atau denda paling banyak Rp5.000.000.000,00 (lima miliar rupiah).

Unsur Objektif atau perbuatan yang dilarang dalam rumusan pasal di atas adalah "menjual satuan lingkungan perumahan atau Lisiba yang belum menyelesaikan status hak atas tanahnya". Sedangkan unsur subjektif dari Pasal 154 adalah "setiap orang".

\section{Pasal 155}

Ketentuan Pasal 155 mengatur ancaman pidana yang diperuntukkan terhadap badan hukum yabg sengaja melakukan serah terima dan/atau menerima pembayaran lebih dari $80 \%$ (delapan puluh persen) dari pembeli. Rumusan Pasal 155 menyebutkan sebagai berikut: ${ }^{25}$

Badan hukum yang dengan sengaja melakukan serah terima dan/atau menerima pembayaran lebih dari 80\% (delapan puluh persen) dari pembeli sebagaimana dimaksud dalam Pasal 138, dipidana dengan pidana kurungan paling lama 1 (satu) tahun atau denda paling banyak Rp1.000.000.000,00 (satu miliar rupiah).

Unsur subjektif pasal di atas adalah "badan hukum" dan "dengan sengaja", sedangkan unsur objektifnya berupa "melakukan serah terima dan/atau menerima pembayaran lebih dari $80 \%$ (delapan puluh persen) dari pembeli".

6. Pasal 156

Sama halnya dengan ketentuan Pasal 155, unsur subjektif Pasal 156 selain "setiap orang” juga berupa "dengan sengaja”. Secara lebih rinci, Pasal 156 menyebutkan sebagai berikut: ${ }^{26}$

Setiap orang yang dengan sengaja membangun perumahan dan/atau permukiman di luar kawasan yang khusus diperuntukkan bagi perumahan dan permukiman sebagaimana dimaksud dalam Pasal 139, dipidana dengan pidana penjara paling lama 2 (dua) tahun atau denda paling banyak Rp2.000.000.000,00 (dua miliar rupiah).

Jika merujuk pada ketentuan Pasal 139 unsur objektif dalam pasal di atas adalah "membangun perumahan dan/atau permukiman di luar kawasan yang khusus diperuntukkan bagi perumahan dan permukiman".

\section{Pasal 157}

Esensi delik dalam ketentuan Pasal 157 merupakan delik komisi, bukan delik omisi karena perbuatan yang dilarang berupa membangun perumahan, dan/atau permukiman di tempat yang berpotensi dapat menimbulkan bahaya bagi barang ataupun orang. Frasa "membangun perumahan, dan/atau permukiman di tempat yang berpotensi dapat

\footnotetext{
${ }^{25}$ Ibid., Pasal 155.

${ }^{26}$ Ibid., Pasal 156.
} 
menimbulkan bahaya" harus dimaknai sebagai perbuatan aktif dan tidak mungkin dengan perbuatan pasif karena mensyaratkan adanya gerakan tubuh (bodily mevement) dari pelaku tindak pidana. Pasal 157 dirumuskan sebagai berikut: ${ }^{27}$

Setiap orang yang dengan sengaja membangun perumahan, dan/atau permukiman di tempat yang berpotensi dapat menimbulkan bahaya bagi barang ataupun orang sebagaimana dimaksud dalam Pasal 140, dipidana dengan pidana kurungan paling lama 1 (satu) tahun atau denda paling banyak Rp50.000.000,00 (lima puluh juta rupiah).

Unsur objektif pasal di atas adalah "membangun perumahan, dan/atau permukiman di tempat yang berpotensi dapat menimbulkan bahaya bagi barang ataupun orang", sedangkan unsur subjektif Pasal 157 adalah "setiap orang" dan dengan sengaja.

8. Pasal 158

Rumusan Pasal 158 menyatakan sebagai berikut: ${ }^{28}$

Setiap pejabat yang dengan sengaja mengeluarkan izin pembangunan rumah, perumahan, dan/atau permukiman yang tidak sesuai dengan fungsi dan pemanfaatan ruang sebagaimana dimaksud dalam Pasal 141 dipidana dengan pidana penjara paling lama 5 (lima) tahun atau denda paling banyak Rp5.000.000.000,00 (lima miliar rupiah).

Pasal 158 tersebut hanya mungkin dilakukan oleh subjek hukum delik dengan kategori tertentu, yakni pejabat pemberi izin pembangunan. Makna pejabat di sini harus dibatasi maknanya pada menteri, gubernur, dan bupati/walikota. Mengapa demikian? Hal ini berdasarkan rumusan Pasal 5, dimana di dalam Pasal 5 ayat (1) disebutkan: "Negara bertanggung jawab atas penyelenggaraan perumahan dan kawasan permukiman yang pembinaannya dilaksanakan oleh pemerintah". ${ }^{29}$ Sedangkan dalam Pasal 5 ayat (2) menyebutkan: "Pembinaan sebagaimana dimaksud pada ayat (1) dilaksanakan oleh menteri pada tingkat nasional; b. gubernur pada tingkat provinsi; dan bupati/walikota pada tingkat kabupaten/kota. ${ }^{30}$ Pembinaan yang dimaksud dalam Pasal 5 ayat (2) meliputi: $:^{31}$
a. perencanaan;
b. pengaturan;
c. pengendalian; dan
d. pengawasan.

Jika melihat lingkup pembinaan di atas, ijin pembangunan rumah, perumahan, dan/atau permukiman merupakan bagian dari wewenang dan tanggung jawab pejabat dalam

\footnotetext{
${ }^{27}$ Ibid., Pasal 157.

${ }^{28}$ Ibid., Pasal 158.

${ }^{29}$ Ibid., Pasal 5 ayat (1).

${ }^{30}$ Ibid., Pasal 5 ayat (2)

${ }^{31}$ Ibid., Pasal 6 ayat (1).
} 
upaya pembinaan atas penyelenggaraan perumahan dan kawasan permukiman. Secara teoritis, pejabat yang mengeluarkan izin pembangunan rumah, perumahan, dan/atau permukiman yang tidak sesuai dengan fungsi dan pemanfaatan ruang dipidana. Hal ini didasarkan pada pemikiran bahwa hal itu memperlemah legitimasi otoritas pemerintah dan mendorong warga negara untuk tidak mematuhi hukum. Apabila pejabat yang seharusnya memberikan contoh kepatuhan terhadap hukum melanggar hukum, warga akan menjadikan hal itu sebagai dasar untuk juga melanggar hukum.

\section{Pasal 159}

Delik dalam Pasal 159 adalah delik komisi sebab perbuatan yang dilarang mensyaratkan adanya gerakan tubuh berupa "menolak atau menghalang-halangi kegiatan pemukiman kembali rumah, perumahan, atau pemukiman". Secara eksplisit Pasal 159 berbunyi sebagai berikut:

Setiap orang yang dengan sengaja menolak atau menghalang-halangi kegiatan pemukiman kembali rumah, perumahan, atau pemukiman yang telah ditetapkan oleh Pemerintah atau pemerintah daerah setelah terjadi kesepakatan dengan masyarakat setempat sebagaimana dimaksud dalam Pasal 142, dipidana dengan pidana kurungan paling lama 1 (satu) tahun atau denda paling banyak Rp100.000.000,00 (seratus juta rupiah). ${ }^{32}$

Karena rumusan pasal tersebut bersifat umum dengan menggunakan frasa "setiap orang", kita tidak bisa membatasi pelaku delik khusus orang-orang atau korporasi tertentu. Jadi siapa pun dapat menjadi pelaku delik Pasal 159 sepanjang perbuatannya berupa "menolak atau menghalang-halangi kegiatan pemukiman kembali rumah, perumahan, atau pemukiman yang telah ditetapkan oleh Pemerintah atau pemerintah daerah setelah terjadi kesepakatan dengan masyarakat setempat".

Unsur objektif pasal tersebut adalah "menolak atau menghalang-halangi kegiatan pemukiman kembali rumah, perumahan, atau pemukiman yang telah ditetapkan oleh Pemerintah atau pemerintah daerah setelah terjadi kesepakatan dengan masyarakat setempat", sedangkan unsur subjektifnya adalah "setiap orang" dan "dengan sengaja".

10. Pasal 160

Rumusan Pasal 160 menyebutkan sebagai berikut:

Setiap orang yang dengan sengaja menginvestasikan dana dari pemupukan dana tabungan perumahan selain untuk pembiayaan kegiatan penyelenggaraan perumahan dan kawasan permukiman sebagaimana dimaksud dalam Pasal 143, dipidana dengan

\footnotetext{
${ }^{32}$ Ibid., Pasal 159.
} 
pidana penjara paling lama 5 (lima) tahun atau denda paling banyak Rp50.000.000.000,00 (lima puluh miliar rupiah). ${ }^{33}$

Berdasarkan rumusan pasal tersebut, unsur objektif dari Pasal 160 adalah "menginvestasikan dana dari pemupukan dana tabungan perumahan selain untuk pembiayaan kegiatan penyelenggaraan perumahan dan kawasan permukiman”. Sementara itu, unsur subjektifnya adalah "setiap orang" dan "dengan sengaja". Karena makna setiap orang dapat berupa perseorangan ataupun korporasi, pelaku delik Pasal 160 bisa siapa saja dan tidak harus disyaratkan memiliki kualifikasi tertentu.

\section{Pasal 161}

Berbeda dengan substansi delik dalam Pasal 160 yang unsur subjektifnya "setiap orang", dalam Pasal 161 ayat (1) unsur subjektifnya selain "dengan sengaja" adalah "orang perorangan”. Makna setiap orang dengan makna orang perorangan jelas berbeda. Jika makna setiap orang dapat berupa perseorangan ataupun korporasi, sedangkan makna orang perorangan tidak termasuk korporasi. Adapun rumusan Pasal 161 ayat (1) berbunyi sebagai berikut:

Orang perseorangan yang dengan sengaja membangun Lisiba sebagaimana dimaksud dalam Pasal 145 ayat (2), dipidana dengan pidana denda paling banyak Rp500.000.000,00 (lima ratus juta rupiah). ${ }^{34}$

Unsur objektif dari Pasal 161 ayat (1) adalah "membangun Lisiba". Lisiba merupakan kependekan dari lingkungan siap bangun. Di dalam Pasal 1 angka 16 disebutkan bahwa: lingkungan siap bangun yang selanjutnya disebut Lisiba adalah sebidang tanah yang fisiknya serta prasarana, sarana, dan utilitas umumnya telah dipersiapkan untuk pembangunan perumahan dengan batas-batas kaveling yang jelas dan merupakan bagian dari kawasan siap bangun sesuai dengan rencana rinci tata ruang. ${ }^{35}$

Pasal 161 ayat (2) merupakan pidana tambahan selain pidana yang disebutkan dalam Pasal 161 ayat (1). Substansi Pasal 161 ayat (2) adalah sebagai berikut:

Selain pidana sebagaimana dimaksud pada ayat (1), pelaku dapat dipidana dengan pidan tambahan berupa pembongkaran Lisiba yang biayanya ditanggung oleh pelaku. $^{36}$

Sanksi pidana dalam Pasal 161 ayat (1) dan ayat (2) merupakan sanksi terhadap pelaku delik yang melanggar norma larangan yang diatur dalam Pasal 145 ayat (2). Pidana tersebut bersifat kumulatif, bukan alternatif. Artinya terhadap pelaku delik yang melakukan perbuatan

\footnotetext{
${ }^{33}$ Ibid., Pasal 160.

${ }^{34}$ Ibid., Pasal 161 ayat (1).

${ }^{35}$ Ibid., Pasal 1 angka 16.

${ }^{36}$ Ibid., Pasal 161 ayat (2).
} 
sebagaimana dimaksud dalam Pasal 145 ayat (2) dikenakan 2 sanksi pidana sekaligus. Rumusan Pasal 145 ayat (2) adalah: "Orang perseorangan dilarang membangun Lisiba". 37

\section{Pasal 162}

Rumusan Pasal 162 ayat (1) adalah sebagai berikut: ${ }^{38}$

Dipidana dengan pidana denda paling banyak Rp5.000.000.000,00 (lima miliar rupiah), Badan Hukum yang:

a. mengalihfungsikan prasarana, sarana, dan utilitas umum diluar fungsinya sebagaimana dimaksud dalam Pasal 144;

b. menjual satuan permukiman sebagaimana dimaksud dalam Pasal 145 ayat (1); atau

c. membangun lisiba yang menjual kaveling tanah matang tanpa rumah sebagaimana dimaksud dalam Pasal 146 ayat (1).

Berdasarkan rumusan pasal tersebut, unsur objektif meliputi: (a) mengalihfungsikan prasarana, sarana, dan utilitas umum diluar fungsinya; (b) menjual satuan permukiman; (c) membangun lisiba yang menjual kaveling tanah matang tanpa rumah. Ketiga perbuatan tersebut sifatnya alternatif, dalam arti tidak perlu ketiganya dilakukan semua oleh pelaku delik, melainkan cukup salah satunya saja. Yang dimaksud dengan "menjual kaveling tanah matang tanpa rumah" adalah suatu kegiatan badan hukum yang dengan sengaja hanya memasarkan kaveling tanah matang kepada konsumen tanpa membangun rumah terlebih dahulu. Penjualan kaveling tanah matang kepada konsumen hanya dapat dilakukan apabila badan hukum tersebu telah membangun perumahan sekurang-kurangnya $25 \%$ dari rencana pembangunan perumahan di Lisiba dan dalam keadaan terjadi krisis moneter nasional yang berakibat pada kesulitan likuiditas pada badan hukum tersebut. Sementara itu, unsur subjektifnya adalah "badan hukum”.

Pasal 162 ayat (2) merupakan pidana tambahan selain pidana denda yang dirumuskan dalam Pasal 162 ayat (1). Rumusan Pasal 162 ayat (2) adalah: "Selain pidana bagi badan hukum sebagaimana dimaksud pada ayat (1), pengurus badan hukum dapat dijatuhi pidana dengan pidana penjara paling lama 5 (lima) tahun”. Hal yang membedakan antara Pasal 162 ayat (1) dengan Pasal 162 ayat (2) adalah, jika dalam Pasal 162 ayat (1) unsur subjektifnya "badan hukum", maka untuk Pasal 162 ayat (2) unsur subjektifnya "pengurus badan hukum". Mengapa unsur subjektif Pasal 162 ayat (2) pengurus badan hukum? Karena sanksi pidana yang diancamkan adalah hukuman badan berupa pidana penjara.

13. Pasal 163

\footnotetext{
${ }^{37}$ Ibid., Pasal 145 ayat (2).

${ }^{38}$ Ibid., Pasal 162 ayat (1).
} 
Pasal 163 mengatur tentang pemberatan pidana bagi badan hukum. Rumusan pasalnya adalah sebagai berikut:

Dalam hal perbuatan sebagaimana dimaksud dalam Pasal 151 ayat (1), Pasal 152, Pasal 153, Pasal 154, Pasal 156, Pasal 157, Pasal 160, atau Pasal 161 dilakukan oleh badan hukum, maka selain pidana penjara dan pidana denda terhadap pengurusnya, pidana dapat dijatuhkan terhadap badan hukum berupa pidana denda dengan pemberatan 3 (tiga) kali dari pidana denda terhadap orang.

Unsur subjektif dari Pasal 163 adalah "badan hukum”. Sedangkan unsur objektifnya meliputi unsur objektif yang diatur Pasal 151 ayat (1), Pasal 152, Pasal 153, Pasal 154, Pasal 156, Pasal 157, Pasal 160, dan Pasal 161. Jika diperinci, unsur objektif dari Pasal 163 meliputi:

a. menyelenggarakan pembangunan perumahan, yang tidak membangun perumahan sesuai dengan kriteria, spesifikasi, persyaratan, prasarana, sarana, dan utilitas umum yang diperjanjikan;

b. menyewakan atau mengalihkan kepemilikannya atas rumah umum kepada pihak lain;

c. menyelenggarakan lingkungan hunian atau Kasiba yang tidak memisahkan lingkungan hunian atau Kasiba menjadi satuan lingkungan perumahan atau lisiba;

d. menjual satuan lingkungan perumahan atau Lisiba yang belum menyelesaikan status hak atas tanahnya;

e. membangun perumahan dan/atau permukiman di luar kawasan yang khusus diperuntukkan bagi perumahan dan permukiman;

f. membangun perumahan, dan/atau permukiman di tempat yang berpotensi dapat menimbulkan bahaya bagi barang ataupun orang;

g. menginvestasikan dana dari pemupukan dana tabungan perumahan selain untuk pembiayaan kegiatan penyelenggaraan perumahan dan kawasan permukiman;

h. membangun Lisiba.

Ancaman pidana dalam Pasal 163, selain berupa pidana penjara dan pidana denda terhadap pengurus badan hukum, juga pidana dapat dijatuhkan terhadap badan hukumnya berupa pidana denda dengan pemberatan 3 (tiga) kali dari pidana denda terhadap perorangan.

\section{B. Penegakan Hukum Pidana Terhadap Tindak Pidana di Bidang Perumahan dan Kawasan Permukiman Berdasarkan Undang-Undang Nomor 1 Tahun 2011 Tentang Perumahan dan Kawasan Permukiman}

Penegakan hukum pidana terhadap tindak pidana di bidang perumahan dan kawasan permukiman masih sangat minim sekali. Hal ini dikarenakan di dalam Undang-Undang Nomor 1 Tahun 2011 tentang Perumahan dan Kawasan Permukiman, selain mengatur sanksi pidana juga mengatur sanksi administrasi. Ketika terjadi pelanggaran di bidang perumahan dan kawasan permukiman, lebih banyak diselesaikan dengan hukum administrasi daripada hukum pidana, karena sifat hukum pidana yang menderitakan. Namun dari sekian banyak 
pelanggaran terhadap Undang-Undang Nomor 1 Tahun 2011 tentang Perumahan dan Kawasan Permukiman yang diselesaikan dengan sanksi administratif, penulis menemukan sebuah putusan pengadilan yang telah mempunyai kekuatan hukum tetap (inkracht). Kasus yang pernah ada terhadap penegakan hukum pidana di bidang perumahan dan kawasan permukiman salah satunya pernah terjadi di Kota Padang, dengan terdakwa Elvi Madreani yang oleh Pengadilan Negeri Padang, terdakwa dinyatakan terbukti bersalah melakukan tindak pidana di bidang perumahan dan kawasan permukiman dan dijatuhkan hukuman pidana penjara selama 1 (satu) tahun.

Berdasarkan putusan Pengadilan Negeri Padang Nomor 46/Pid.Sus/2018/PN Pdg yang mengadili perkara pidana atas nama Elvy Madreani terdakwa dinyatakan terbukti bersalah melakukan tindak pidana "menjual satuan lingkungan perumahan atau lisiba yang belum menyelesaikan status hak atas tanahnya" sebagaimana diatur dalam Pasal 154 UndangUndang Nomor 1 Tahun 2011 tentang Perumahan dan Kawasan Permukiman, sehingga terdakwa Elvy Madreani dijatuhkan pidana penjara selama 1 (satu tahun) oleh Pengadilan Negeri Padang. Namun majelis hakim menetapkan pidana tersebut tidak usah dijalani kecuali dikemudian hari ada putusan hakim yang menentukan lain disebabkan karena terpidana melakukan suatu tindak pidana sebelum masa percobaan berakhir.

Pada tingkat banding di Pengadilan Tinggi Padang, majelis hakim memutus terdakwa Elvi Madreani, S.H. terbukti melakukan perbuatan yang didakwakan kepadanya akan tetapi perbuatan tersebut bukan merupakan suatu tindak pidana, atau dengan kata lain melepaskan terdakwa dari segala tuntutan hukum. Putusan Pengadilan Tinggi Padang tersebut dituangkan dalam putusan nomor 116/PID.SUS/2018/PT PDG. Pada tingkat kasasi di Mahkamah Agung, permohonan kasasi Penuntut Umum dikabulkan oleh Mahkamah Agung sekaligus membatalkan Putusan Pengadilan Tinggi Padang nomor 116/PID.SUS/2018/PT PDG tanggal 4 Oktober 2018 yang membatalkan Putusan Pengadilan Negeri Padang Nomor 46/Pid.Sus/2018/PN Pdg tanggal 26 Juni 2018. Selain itu, Mahkamah Agung juga menyatakan terdakwa Elvy Madreani terbukti secara sah dan meyakinkan bersalah melakukan tindak pidana "menjual satuan lingkungan perumahan atau lisiba yang belum menyelesaikan status hak atas tanahnya". Mahkamah Agung juga menjatuhkan pidana kepada terdakwa Elvy Madreani dengan pidana penjara 1 (satu) tahun, dan memerintahkan agar terdakwa ditahan. Putusan Mahkamah Agung ini tertuang dalam putusan nomor 635 K/Pid.Sus/2019.

Terpidana Elvy Madreani selaku Direktur CV. Devindo Artha Development pada awal tahun 2013 telah membangun perumahan Pondok Indah Balai Baru yang terletak di Jalan 
Wisma Indah VI RT.03/RW.07 Kelurahan Gunung Sariak, Kecamatan Kuranji, Kota Padang, dengan luas tanah $14.330 \mathrm{~m}^{2}$, yang dibangun rumah sebanyak 31 unit dengan berbagai ukuran yang terdiri dari type 36, type 45, type 60, dan type 70, yang berhasil dijual sebanyak 26 unit dengan pembayaran bertahap dan kredit. ${ }^{39}$ Padahal rumah yang dijual tersebut status tanahnya masih belum jelas dan masih dalam sengketa kepemilikan sehingga tanah tersebut belum dapat diterbitkan sertifikatnya oleh BPN Kota Padang. ${ }^{40}$ Selain itu, IMB, Ijin Prinsip, Ijin lokasi, dan Surat Keterangan Rencana Kota (KRK) Izin Pengkavlingan juga terdakwa tidak memiliki.

Mengenai frasa "belum menyelesaikan status hak atas tanahnya" sebagaimana dimaksud dalam unsur Pasal 154 Undang-Undang Nomor 1 Tahun 2011 tentang Perumahan dan Kawasan Permukiman, dapat diartikan status kepemilikan atas tanah tersebut belum beralih kepada konsumen atau masih ada kepentingan pihak ketiga atau masih dibebani hak tanggungan yang dapat mengakibatkan ketidakpastian hukum bagi masyarakat sebagai konsumen bidang perumahan. Ketentuan dalam Pasal 42 dan Pasal 43 Undang-Undang Nomor 1 Tahun 2011 tentang Perumahan dan Kawasan Permukiman menentukan bahwa salah satu persyaratan yang harus dipenuhi oleh pengembang adalah status hak atas tanah tempat berdirinya bangunan tersebut, status hak atas tanah menunjukan kepemilikan atas tanah tersebut dan memastikan bahwa tanah tersebut tidak dalam bersengketa dengan pihak ketiga atau dikenakan hak tangungan sebagai jaminan kepada pihak ketiga yang dapat merugikan konsumen, sesuai Pasal 137 Undang-Undang Nomor 1 Tahun 2011 tentang Perumahan dan Kawasan Permukiman sudah diatur dengan tegas larangan menjual satuan lingkungan siap bangun yang belum selesai status hak atas tanahnya. Lingkungan siap bangun (lisiba) menurut ketentuan Pasal 1 angka 16 Undang-Undang Nomor 1 Tahun 2011 tentang Perumahan dan Kawasan Permukiman adalah sebidang tanah yang fisiknya serta prasarana, sarana, utilitas umumnya telah dipersiapkan untuk pembangunan perumahan dengan batasbatas kaveling yang jelas dan merupakan bagian dari kawasan siap bangun sesuai dengan rencana rinci tata ruang ${ }^{41}$. Mengenai ketentuan status tanah yang bisa mendirikan satuan lingkungan perumahan atau lingkungan siap bangun (lisiba) adalah yang jelas kepemilikannya, yaitu berupa hak milik, hak guna bangunan atau hak pakai yang bebas sengketa, artinya tidak terkait dengan kepentingan pihak ketiga atau dijadikan jaminan kepada

\footnotetext{
${ }^{39}$ Putusan Nomor 46/Pid.Sus/2018/PN Pdg., hlm. 9.

${ }^{40}$ Ibid., hlm. 10.

${ }^{41}$ Op.Cit., Pasal 1 angka 16 Undang-Undang Nomor 1 Tahun 2011 Tentang Perumahan dan Kawasan
} Permukiman. 
pihak ketiga. Pengembang yang menyelenggarakan rumah tapak, rumah deret atau rumah susun yang belum menyelesaikan status hak atas tanahnya dapat dikenakan sanksi administratif sesuai ketentuan Pasal 150 dan sanksi pidana sesuai ketentuan Pasal 154 Undang-Undang Nomor 1 Tahun 2011 berupa pidana penjara paling lama 5 (lima) tahun atau denda paling banyak Rp5.000.000.000 (lima miliar rupiah)

\section{Analisis Terhadap Putusan Mahkamah Agung Nomor 635 K/Pid.Sus/2019 Atas Perkara Tindak Pidana di Bidang Perumahan dan Kawasan Permukiman}

Putusan Kasasi oleh Mahkamah Agung nomor 635 K/Pid.Sus/2019 atas permohonan kasasi dari Penuntut Umum pada Kejaksaan Negeri Padang merupakan upaya hukum yang dilakukan Penuntut Umum Kejaksaan Negeri Padang atas ketidakpuasan terhadap putusan Pengadilan Tinggi Padang Nomor 116/PID.SUS/2018/PT PDG tanggal 4 Oktober 2018 yang telah membatalkan putusan Pengadilan Negeri Padang Nomor 46/Pid.Sus/2018/PN Pdg pada tanggal 26 Juni 2018. Dalam putusan banding Pengadilan Tinggi Padang tersebut, majelis hakim menyatakan terdakwa Elvy Madreani terbukti melakukan perbuatan yang didakwakan kepadanya, akan tetapi perbuatan tersebut bukan merupakan suatu tindak pidana. Oleh karenanya majelis hakim melepaskan terdakwa Elvy Madreani, S.H. dari segala tuntutan hukum.

Padahal dalam putusan pengadilan tingkat pertama di Pengadilan Negeri Padang, terdakwa Elvy Madreani dinyatakan terbukti bersalah melakukan tindak pidana "menjual satuan lingkungan perumahan atau lisiba yang belum menyelesaikan status hak atas tanahnya" sebagaimana diatur dalam Pasal 154 Undang-Undang Nomor 1 Tahun 2011 tentang Perumahan dan Kawasan Permukiman, sehingga terdakwa Elvy Madreani, S.H. dijatuhkan pidana penjara selama 1 (satu tahun) oleh Pengadilan Negeri Padang.

Pada tingkat kasasi di Mahkamah Agung, permohonan kasasi Penuntut Umum dikabulkan oleh Mahkamah Agung sekaligus membatalkan Putusan Pengadilan Tinggi Padang nomor 116/PID.SUS/2018/PT PDG tanggal 4 Oktober 2018 yang membatalkan Putusan Pengadilan Negeri Padang Nomor 46/Pid.Sus/2018/PN Pdg tanggal 26 Juni 2018. Selain itu, Mahkamah Agung juga menyatakan terdakwa Elvy Madreani terbukti secara sah dan meyakinkan bersalah melakukan tindak pidana "menjual satuan lingkungan perumahan atau lisiba yang belum menyelesaikan status hak atas tanahnya". Mahkamah Agung juga menjatuhkan pidana kepada terdakwa Elvy Madreani dengan pidana penjara 1 (satu) tahun, dan memerintahkan agar terdakwa ditahan. 
Jika penulis analisis, perbedaan putusan kasasi dan putusan banding atas perkara terdakwa Elvy Madreani terletak dari cara pandang majelis hakim dalam melihat perbuatan terdakwa. Dalam putusan kasasi nomor 635 K/Pid.Sus/2019, majelis hakim menilai perbuatan yang dilakukan oleh terdakwa merupakan tindak pidana, sedangkan dalam putusan banding, majelis hakim menilai perbuatan yang dilakukan oleh terdakwa bukan merupakan tindak pidana, tetapi perbuatan keperdataan. Perbuatan menjual satuan lingkungan perumahan atau lisiba yang belum menyelesaikan status hak atas tanahnya merupakan perbuatan dalam aspek keperdataan, yaitu perjanjian jual beli. Melihat syarat sahnya suatu perjanjian jual beli tentu saja mengacu ke pasal 1320 Kitab Undang-Undang Hukum Perdata. Di dalam pasal 1320 Kitab Undang-Undang Hukum Perdata sendiri, menyebutkan adanya 4 (empat) syarat sahnya suatu perjanjian, yaitu:

1. Adanya kata sepakat bagi mereka yang mengikatkan dirinya;

2. Kecakapan para pihak untuk membuat suatu perikatan;

3. Suatu hal tertentu; dan

4. Suatu sebab (causa) yang halal.

Sementara itu, hubungan hukum antara terdakwa Elvi Madreani dengan para korban (pembeli rumah) adalah terikat dengan hukum perjanjian, sehingga telah memasuki wilayah hukum keperdataan, oleh karena itu majelis hakim tingkat banding menyatakan bahwa terdakwa Elvi Madreani telah melakukan perbuatan yang didakwakan kepadanya (menjual satuan lingkungan perumahan atau lisiba yang belum menyelesaikan status hak atas tanahnya), akan tetapi perbuatan itu bukanlah merupakan suatu tindak pidana (onslag van rechtvervolding).

Namun dengan melihat putusan kasasi Mahkamah Agung nomor 635 K/Pid.Sus/2019 terhadap terdakwa Elvi Madreani tersebut, dapat dikatakan bahwa para penegak hukum kita, baik kepolisian, jaksa, maupun hakim, masih mengakui eksistensi hukum pidana yang terdapat dalam Undang-Undang Nomor 1 Tahun 2011. Hukum pidana di bidang perumahan dan kawasan permukiman masih diperlukan dan tidak kehilangan wibawanya karena masih dijadikan dasar hukum dalam putusan pengadilan. Hal ini dapat dijadikan peringatan terhadap pihak-pihak yang berusaha di bidang perumahan apabila melakukan tindak pidana di bidang perumahan dan kawasan permukiman.

Namun sangat disayangkan, perkara tindak pidana di bidang perumahan dan kawasan permukiman yang diputus oleh pengadilan pasca diundangkannya Undang-Undang Nomor 1 Tahun 2011 tentang Perumahan dan Kawasan Permukiman masih sangat minim. Dari 
pencarian penulis di Direktori Putusan Mahkamah Agung Republik Indonesia, penulis hanya menemukan putusan terhadap terdakwa Elvi Madreani yang menggunakan Undang-Undang Nomor 1 Tahun 2011 tentang Perumahan dan Kawasan Permukiman, selebihnya adalah tindak pidana "menghuni rumah tanpa ijin pemiliknya yang sah" sebagaimana diatur dan diancam pidana Pasal 36 ayat (4) juncto Pasal 12 ayat (1) Undang-Undang Nomor 4 Tahun 1992 tentang Perumahan dan Permukiman. ${ }^{42}$

Sebagaimana diketahui, Undang-Undang Nomor 4 Tahun 1992 tentang Perumahan dan Pemukiman pada tanggal 12 Januari 2011 telah dicabut dan dinyatakan tidak berlaku, kemudian diganti dengan Undang-Undang Nomor 1 Tahun 2011 tentang Perumahan dan Kawasan Permukiman. Undang-Undang Nomor 1 Tahun 2011 tentang Perumahan dan Kawasan Permukiman tidak lagi mengatur ancaman pidana terhadap perbuatan yang diatur dan diancam pidana dalam Pasal 12 Ayat (1) juncto Pasal 36 Ayat (4) Undang-Undang Nomor 4 Tahun 1992, akan tetapi dalam Bab XIV tentang Penyelesaian Sengketa dalam Pasal 147, 148 dan Pasal 149 mengatur bahwa penyelesaian sengketa di bidang perumahan terlebih dahulu diupayakan berdasarkan musyawarah untuk mufakat, namun apabila musyawarah itu tidak tercapai, pihak yang dirugikan dapat mengajukan gugatan perdata melalui pengadilan (peradilan umum). Artinya "perbuatan menghuni rumah tanpa ijin pemiliknya yang sah" tidak dipandang tindak pidana lagi oleh Undang-Undang Nomor 1 Tahun 2011 tentang Perumahan dan Kawasan Permukiman, atau bisa dikatakan sebagai dekriminalisasi dan depenalisasi.

Sebagai contoh, dalam putusan Pengadilan Negeri Bale Bandung No. 138/PID.Sus/2014/PN BB atas nama terdakwa Cece Mulyana bin H. Mamat, majelis hakim menyatakan terdakwa bersalah melakukan tindak pidana "menghuni rumah tanpa ijin pemiliknya yang sah", dan majelis hakim menjatuhkan pidana penjara selama 10 (sepuluh) bulan. Jika perbuatan terdakwa Cece Mulyana bin H. Mamat dilakukan setelah disahkannya Undang-Undang Nomor 1 Tahun 2011 tentang Perumahan dan Kawasan Permukiman, maka hal tersebut tidak dipandang sebagai tindak pidana.

\section{PENUTUP}

\section{Kesimpulan}

${ }^{42}$ Pasal 36 ayat (4) jo Pasal 12 ayat (1) UU No. 4 Tahun 1992 Tentang Perumahan dan Permukiman. 
Berdasarkan uraian di atas, pengaturan pidana di bidang perumahan dan kawasan permukiman berdasarkan Undang-Undang Nomor 1 Tahun 2011 tentang Perumahan dan Kawasan Permukiman, diatur dalam Pasal 151 sampai dengan Pasal 163. Ada 3 (tiga) macam sanksi pidana dalam Undang-Undang Nomor 1 Tahun 2011, yaitu pidana penjara, pidana kurungan, dan denda. Selain pidana penjara, pidana kurungan dan denda, Undang-Undang Nomor 1 Tahun 2011 juga menetapkan sanksi tambahan yang terdapat dalam Pasal 151 ayat (2), Pasal 153 ayat (3), dan Pasal 161 ayat (2) undang-undang tersebut. Adapun bentuk sanksi tambahan dalam penyelenggaraan perumahan dan kawasan permukiman, antara lain: membangun kembali perumahan sesuai dengan kriteria, spesifikasi, persyaratan, prasarana, sarana, dan utilitas umum; pencabutan izin; dan pembongkaran lingkungan siap bangun yang biayanya ditanggung oleh pelaku. Namun, setelah terbitnya Undang-Undang Nomor 11 Tahun 2020 Tentang Cipta Kerja, sanksi pidana tambahan yang terdapat dalam Pasal 151 ayat (2) dan Pasal 153 ayat(2) telah dicabut, sehingga saat ini pidana tambahan yang masih ada hanya terdapat di dalam Pasal 161 ayat (2) dengan bentuk pidana tambahan berupa pembongkaran lingkungan siap bangun yang biayanya ditanggung oleh pelaku. Pada dasarnya selain pencabutan pidana tambahan yang terdapat dalam Pasal 151 ayat (2) dan Pasal 153 ayat (2) tersebut, Undang-Undang Nomor 11 Tahun 2020 tentang Cipta Kerja juga melakukan depenalisasi dan dekriminalisasi dengan menghapus sanksi pidana yang terdapat dalam Pasal 153 ayat (1) Undang-Undang Nomor 1 Tahun 2011 tentang Perumahan dan Kawasan Permukiman. Ketentuan pidana yang telah diubah oleh Undang-Undang Nomor 11 Tahun 2020 menjadi sanksi administratif. Sebelum dilakukan perubahan oleh Undang-Undang Nomor 11 Tahun 2020, ancaman pidana yang terdapat dalam Pasal 153 ayat (1) adalah pidana denda paling banyak Rp5.000.000.000,00 (lima miliar rupiah), yang kemudian oleh UndangUndang Nomor 11 Tahun 2020 tentang Cipta Kerja menjadi sanksi administratif.

Penegakan hukum pidana terhadap tindak pidana di bidang perumahan dan kawasan permukiman, khususnya penegakan hukum yudikatif, masih minim yang sampai ke tingkat persidangan. Hal ini disebabkan karena tindak pidana yang diatur dalam Undang-Undang Nomor 1 Tahun 2011 tentang Perumahan dan Kawasan Permukiman tersebut pada dasarnya bukan merupakan kejahatan murni, melainkan hanya hukum administratif yang diperkuat dengan sarana penal, atau aturan administratif yang diberikan sanksi pidana. Adanya penalisasi tersebut agar Undang-Undang Nomor 1 Tahun 2011 tentang Perumahan dan Kawasan Permukiman tersebut mempunyai marwah dan mempunyai efek jera terhadap pelaku tindak pidananya. Kepentingan yang ingin dilindungi dari undang-undang di bidang 
perumahan dan kawasan permukiman adalah untuk kepentingan masyarakat atau konsumen, serta kepentingan negara, khususnya kepentingan negara dalam bidang perumahan dan kawasan permukiman agar program pemerintah bisa tercapai.

\section{Saran}

1. Pembentuk undang-undang harus berhati-hati menggunakan hukum pidana dan sanksi pidana guna menegakkan norma hukum pidana karena penggunaan hukum pidana dan sanksi yang berlebihan dapat menimbulkan dampak negatif terhadap hukum pidana (inflasi pidana dan pelampauan batas penggunaan hukum pidana) dan penegakan hukum pidana.

2. Pemerintah harus tegas dalam menegakan hukum di bidang perumahan dan kawasan permukiman, khususnya penegakan hukum pidana, agar tujuan dari diundangkannya undang-undang tentang perumahan dan kawasan permukiman bisa dicapai. Konsistensi dalam upaya penegakan hukum, khususnya penegakan hukum pidana juga diperlukan terhadap orang maupun badan hukum yang melanggar ketentuan pidana di bidang perumahan dan kawasan permukiman.

\section{Buku}

\section{DAFTAR PUSTAKA}

Marzuki, 2005, Peter Mahmud, Penelitian Hukum, Surabaya: Kencana.

Moeljatno, 2008, Asas-Asas Hukum Pidana, Jakarta: Renika Cipta.

Prodjodikoro, Wirjono, 1962, Hukum Acara Pidana di Indonesia, Bandung: Sumur.

Sudarto, 1977, Hukum dan Hukum Pidana, Bandung: Alumni.

Van Bemmelen, Mr. J. M., 1987, Hukum Pidana I, Bandung: Bina Cipta.

Yati Nurhayati, Pengantar Ilmu Hukum, Nusa Media, Bandung, 2020.

\section{Peraturan Perundang-Undangan}

Undang-Undang Nomor 10 Tahun 1998 Perubahan Atas Undang-Undang Nomor 7 Tahun 1992 tentang Perbankan

Undang-Undang Nomor 4 Tahun 1992 tentang Perumahan dan Permukiman.

Undang-Undang Nomor 1 Tahun 2011 tentang Perumahan dan Kawasan Permukiman. 
Undang-Undang Nomor 11 Tahun 2020 tentang Cipta Kerja.

Peraturan Pemerintah Nomor 80 Tahun 1999 tentang Kawasan Siap Bangun dan Lingkungan Siap Bangun yang Berdiri Sendiri.

Peraturan Pemerintah Nomor 63 Tahun 2000 tentang Badan Kebijaksanaan dan Pengendalian Pembangunan Perumahan dan Permukiman Nasional.

\section{Jurnal}

Alfian Mardiansyah, Neisa Ang- rum Adisti, 2020. "Analisis Yuridis Pasal 98 Ayat (3) Undang-Undang Nomor 1 Tahun 2011 Tentang Perumahan dan Kawasan Permukiman (Kajian Terhadap Penetapan Lokasi Perumahan Kumuh Oleh Pemerintah Daerah Dengan Peraturan Daerah)", Jurnal Legislasi Indonesia, Volume 17 Nomor 4.

Anih Sri Suryani, 2011. "Tantangan Implementasi Konsep Eco-Settlement Dalam UndangUndang Nomor 1 Tahun 2011 Tentang Perumahan dan Kawasan Permukiman”, Jurnal Aspirasi, Volume 2 Nomor 1.

Astri Putri Aprilla, 2015. "Problematika Hukum Pengaturan Rumah Negara (Inkonsistensi Pasal 51 ayat (2) dan (3) Undang-Undang Nomor 1 Tahun 2011 Dengan Pasal 17 ayat (1) Angka 2 Peraturan Pemerintah Nomor 31 Tahun 2005)", Jurnal Universitas Brawijaya.

Dolfi Sandang, 2015. "Perlindungan Hukum Bagi Konsumen Terhadap Pengembang Perumahan Dalam Perspektif Undang-Undang Nomor 1 Tahun 2011”, Lex et Societatis, Volume 3 Nomor 2.

Dwi Novi Yandri, 2013. "Tanggung Jawab Hukum Pengembang Perumahan Akibat Terjadinya Wanprestasi Dari Perjanjian Kepemilikan Rumah Ditinjau Dari Undang-Undang Nomor 1 Tahun 2011 Tentang Perumahan dan Kawasan Permukiman", Student Research Article Universitas Jember.

Julio Aipassa, 2018. "Pengaturan Sewa Menyewa Menurut Undang-Undang Nomor 1 Tahun 2011 Tentang Perumahan dan Kawasan Permukiman", Lex Privatum, Volume 6 Nomor 7.

Muhammad Aziz Nurhakim, Endang Pandamdari, 2016. "Pemenuhan Atas Sarana dan Utilitas Pada Perumahan Subsidi Mutiara Puri Harmoni Rajeg Tangerang Menurut Undang-Undang Nomor 1 Tahun 2011 Tentang Perumahan dan Permukiman", Jurnal Hukum Adigama.

Nia Kurniati, 2014. "Pemenuhan Hak atas Perumahan dan Kawasan Permukiman yang Layak dan Penerapannya Menurut Kovenan Internasional Hak-hak Ekonomi, Sosial, dan Budaya di Indonesia”, Padjajaran Jurnal Ilmu Hukum, Volume 1 Nomor 5.

Nia Kurniati, 2018. "Pengalihan Hak Rumah Negara Kepada Pegawai Negeri Dalam Penerapan Hukum Sewa Beli”, Jurnal Bina Mulia Hukum, Volume 2 Nomor 2 
Ni Ketut Dewi Megawati, 2016. "Perspektif Undang-Undang Nomor 1 Tahun 2011 tentang Perumahan dan Kawasan Permukiman Terhadap Perlindungan Hak Konsumen Dalam Jual Beli Perumahan", Jurnal Magister Hukum Udayana, Volume 5 Nomor 1.

Nurhayati, Y., Ifrani, I., \& Said, M. Y. (2021). Metodologi Normatif Dan Empiris Dalam Perspektif Ilmu Hukum. Jurnal Penegakan Hukum Indonesia, 2(1), 1-20. https://doi.org/10.51749/jphi.v2i1.

Rifky Tamsir, 2012. "Tinjauan Yuridis Fasilitas Sosial dan Fasilitas Umum Pada Perumahan dan Kawasan Permukiman di Kota Makassar", Fakultas Hukum Universitas Hasanuddin.

Rizaldi Adiwira Mardi Putra, 2016. "Pelaksanaan Undang Undang Nomor 1 Tahun 2011 Tentang Perumahan dan Kawasan Permukiman", Student Journal Universitas Brawijaya.

Scivi, 2017. "Pengaturan Konsolidasi Tanah Untuk Pembangunan Perumahan Menurut UU No. 1 Tahun 2011 Tentang Perumahan dan Kawasan Permukiman", Lex et Societatis, Volume 5 Nomor 6.

Yani Pujiwati, Betty Rubiati, 2017. “Alih Fungsi Lahan Pertanian Untuk Pembangunan Rumah Bagi Masyarakat Berpenghasilan Rendah (MBR) Ditinjau Dari UndangUndang Nomor 1 Tahun 2011 tentang Perumahan dan Kawasan Permukiman dan Undang-Undang Nomor 41 Tahun 2009 tentang Perlindungan Lahan Pertanian Pangan Berkelanjutan", Acta Diurnal, Volume 1 Nomor 1.

Yati Nurhayati, "Perdebatan Metode Normatif dengan Metode Empirik Dalam Penelitian Ilmu Hukum Ditinjau Dari Karakter, Fungsi dan Tujuan Ilmu Hukum”, Jurnal Al Adl, Volume 5 Nomor 10, 2013.

Zinda Zhafira, 2019. "Tinjauan Yuridis Terhadap Tindak Pidana di Bidang Perumahan dan Kawasan Permukiman”, Universitas Sriwijaya. 